Journal of Fish Biology (2010) 0, 0-0

doi:10.1111/j.1095-8649.2010.02771.x, available online at wileyonlinelibrary.com

\title{
Reproductive biology of the starry smooth-hound shark Mustelus asterias: geographic variation and implications for sustainable exploitation
}

\author{
E. D. Farrell*, S. Mariani*† And M. W. Clarke \\ *Marine Biodiversity, Ecology \& Evolution, School of Biology and Environmental Science, \\ University College Dublin, Belfield, Dublin 4, Ireland and $\ddagger$ Marine Institute, Rinville, \\ Oranmore, Co. Galway, Ireland
}

(Received 21 January 2010, Accepted 11 August 2010)

\begin{abstract}
Examination of the reproductive biology of Mustelus asterias in the north-east Atlantic Ocean highlighted apparent geographical variation in maturity, fecundity and ovarian cycle between Atlantic and Mediterranean populations. The stretch total length $\left(L_{\mathrm{ST}}\right)$ and age at $50 \%$ maturity for Atlantic males and females were estimated at $78 \mathrm{~cm} L_{\mathrm{ST}}$ and $4-5$ years and $87 \mathrm{~cm} L_{\mathrm{ST}}$ and 6 years, respectively. Size at maturity of females was considerably smaller than in Mediterranean specimens $\left(96 \mathrm{~cm} L_{\mathrm{ST}}\right)$. Ovarian fecundity ranged from eight to 27 oocytes and uterine fecundity from six to 18 embryos. The gestation period was $c .12$ months, followed by a resting period of $c .12$ months, resulting in a biennial cycle. Females stored sperm in the oviducal gland and, unlike Mediterranean specimens, no uterine compartments were observed in Atlantic specimens. This study reveals the existence of strong, possibly adaptive, divergence in life-history traits in an elasmobranch, whose northern populations may be more susceptible to overexploitation than previously believed. $\odot 2010$ The Authors
\end{abstract} Journal compilation (c) 2010 The Fisheries Society of the British Isles

Key words: elasmobranch; gestation; sperm storage; uterine compartments.

\section{INTRODUCTION}

The K-selected life-history strategies of elasmobranchs and their high position in trophic food webs make them more susceptible to fishing pressure than most teleosts (Stevens et al., 2000). Limited biological information for most species has made it difficult to determine their specific vulnerability to exploitation and has subsequently hampered the implementation of conservation and management measures (Frisk et al., 2001). The problem is further exacerbated, as some species are known to exhibit latitudinal or geographic variability of key life-history traits, which may respond rapidly to exploitation (Kuparinen \& Merila, 2007), often with undesirable effects on populations, fisheries and ecosystems (Myers et al., 2007). Therefore, the accumulation of life-history data should be a priority for biologists, fisheries scientists and resource managers (Cope, 2006).

\footnotetext{
$\dagger$ Author to whom correspondence should be addressed. Tel.: +353 1716 2347; fax: +353 1716 1153;
} email: stefano.mariani@ucd.ie 
The starry smooth-hound Mustelus asterias Cloquet is a relatively small demersal shark whose distribution is limited to continental shelf waters in the north-east Atlantic Ocean, Mediterranean Sea and south to Mauritania (Compagno, 1984). Little is known of its reproductive biology in the north-east Atlantic Ocean due in part to confusion concerning the discrimination of this species from the common smooth-hound Mustelus mustelus (L.) whose range partially overlaps with that of $M$. asterias. The recent development of a molecular genetic identification technique has allowed for the reliable identification and discrimination of north-east Atlantic Mustelus species (Farrell et al., 2009), enabling more detailed study of the genus.

Members of the Mustelus genus are all viviparous; however, they can be separated into two putative clades based on molecular phylogenetic analyses and their respective forms of viviparity (Lopez et al., 2006). Unspotted Mustelus species, such as M. mustelus, develop a placental connection with the mother through the interaction of the yolk sac, egg envelope and uterine wall (Smale \& Compagno, 1997), whereas white-spotted species, such as $M$. asterias, have no physical connection to the mother and rely on the yolk sac during early/stages of development. Once this resource is depleted, additional nutrients and water are absorbed from uterine secretions (Capapé, 1983), known as minimal histotrophy (Hamlett et al., 2005a).

Survey data in the north-east Atlantic Ocean suggest that the abundance of Mustelus spp. has increased in recent years in the Bristol Channel, Celtic Sea and North Sea and has remained stable in the Irish Sea(ICES, 2007). Decreases in abundance and landings, however, have been reported in the southern Bay of Biscay and Portuguese waters (Quero, 1998; Correia \& Smith, 2003). Mediterranean populations have also been severely depleted and possibly locally extirpated in some areas, after decades of overexploitation (Aldebert, 1997; Jukic-Peladic et al., 2001; Ferretti et al., 2005).

The reproductive biology of $M$. asterias has previously been described in Mediterranean waters (Capapé, 1983); however, there have been no studies conducted in the north-east Atlantic Ocean, despite the known geographic variability of reproductive variables in this genus (Francis \& Mace, 1980; Lenanton et al., 1990; Yamaguchi et al., 2000; Walker, 2007). This study presents the most exhaustive investigation to date of the reproductive biology of $M$. asterias in the north-east Atlantic Ocean. The findings were compared with previous data on Mediterranean populations.

\section{MATERIALS AND METHODS}

\section{SAMPLING}

A total of $231 \mathrm{M}$. asterias, comprising 113 males and 118 females, were collected between October 2006 and February 2009 from the Irish Sea, Bristol Channel, Celtic Sea and west of Ireland (Fig. 1). There is no commercial fishery targeting M. asterias in Ireland; therefore, specimen collection was necessarily opportunistic and samples were not available for each month of the year. Specimens included the discards of commercial trawlers, gillnetters and fisheries research vessels. Sex was recorded and stretch total length $\left(L_{\mathrm{ST}}\right)$ was measured (to the $\mathrm{cm}$ below) in a straight line from the tip of the snout to the tip of the upper caudal lobe when in a stretched position; males $35-104 \mathrm{~cm} L_{\mathrm{ST}}$ and females $43-112 \mathrm{~cm} L_{\mathrm{ST}}$ were recorded. Total body mass $\left(M_{\mathrm{T}}\right)$ was measured in $\mathrm{kg}$. Each specimen was dissected with a ventral incision from the cloaca to the pectoral girdle in order to expose the body cavity. During the course of the study 118 M. asterias, caught by hook and line in the Irish Sea 


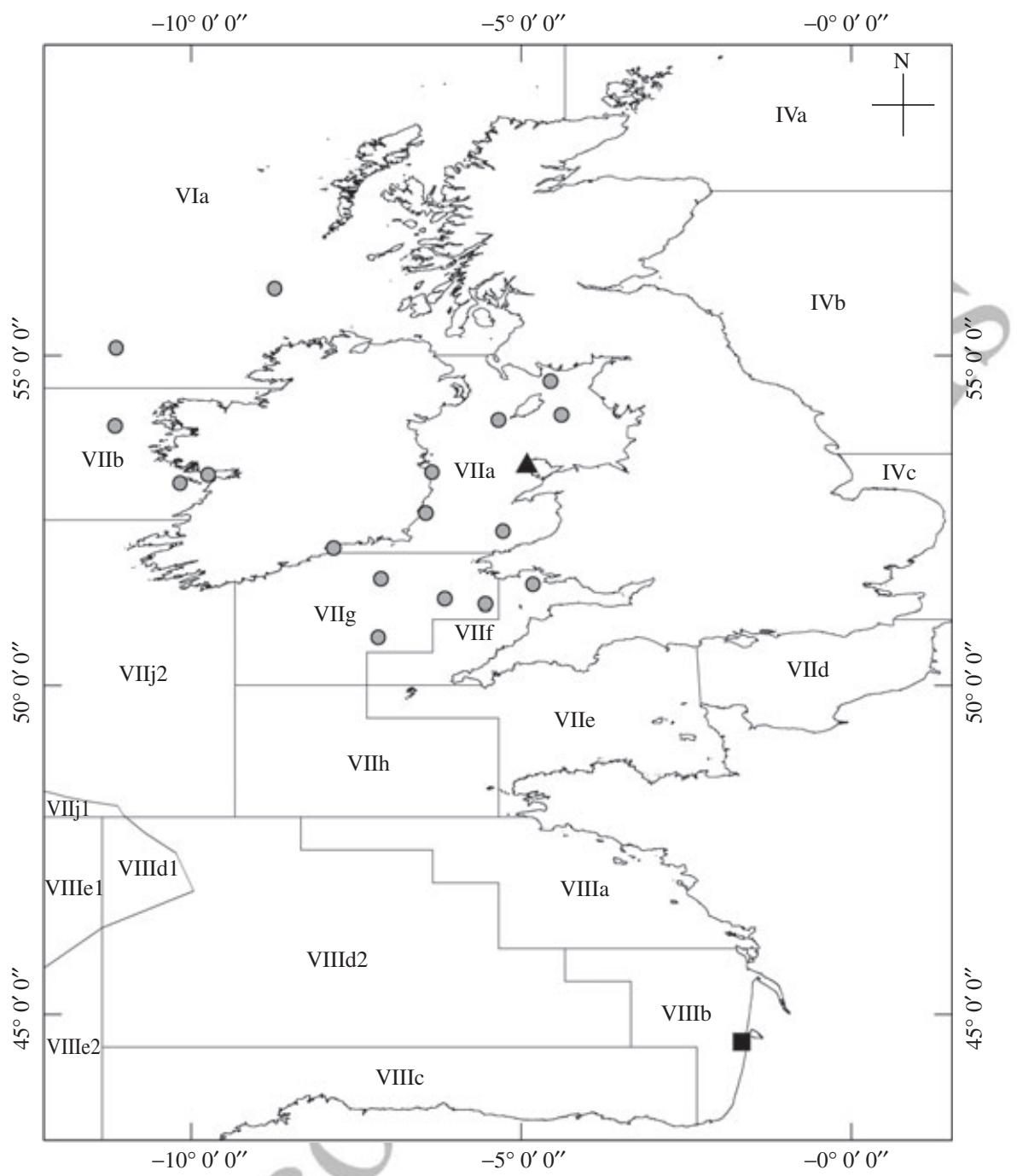

FIG. 1. Distribution of Mustelus asterias samples (O) collected from the north-east Atlantic Ocean for reproductive analyses. The location of tagging $(\boldsymbol{\Delta})$ and recapture $(\boldsymbol{\square})$ of the one returned tag is also shown. Roman numerals indicate ICES assessment areas. High abundance of juveniles has been reported in areas IVc, VIId and VIIf.

(Fig. 1), were tagged in the first dorsal fin with individually numbered white plastic tags (Rototag, Dalton; www.dalton.ie) and released. Due to the potential for misidentification, all specimens in this study were genetically identified using the method illustrated in Farrell et al. (2009).

\section{DATA COLLECTION AND ANALYSES}

\section{Males}

The calcification of claspers and their length in relation to the pelvic fins, the size and appearance of the testes and the coiling of the sperm ducts were assessed to determine 
TABLE I. Mustelus asterias maturity scale used in the current study

C Mature (adult)

A Immature (juvenile)

B Maturing (adolescent)

C Mature (adult)

D Mature (developing)

E Mature (differentiating)

F Mature (expecting)

G Mature (post-natal)

maturity, following a maturity scale (Table I) (Stehmann, 2002). Male clasper length $\left(L_{\mathrm{C}}\right)$ was measured to the nearest $0.1 \mathrm{~cm}$ along the inner margin from the apex of the cloaca to the clasper tip. The rate of growth of $L_{\mathrm{C}}$ in proportion to $L_{\mathrm{ST}}$ and maturity stage was described using locally weighted scatter-plot smoothing (LOESS). Testes length and width were measured to the nearest $0.1 \mathrm{~mm}$ and weighed to the nearest $0.1 \mathrm{~g}$, before fixation in $10 \%$ buffered formalin for histological analyses. Once fixed, a 4 mm thick transverse section was taken from the middle of each testis, dehydrated through a series of 
alcohol and solvent solutions and infiltrated with paraffin on an automatic tissue processor (VIP, Tissue-Tek; www.sakura-americas.com). A rotary microtome (HM 325, Thermo Fischer Scientific Inc.; www.thermofisher.com) was used to cut $4 \mu \mathrm{m}$ thick sections, which were stained with haematoxylin and eosin, cover-slipped with a mounting medium and viewed under an Olympus BX60 light microscope (www.olympusmicro.com). The proportion of the testis section occupied by each stage of spermatogenesis (Maruska et al., 1996; Conrath \& Musick, 2002) was measured in a straight line from the germinal zone across the section. The mean proportion of the testis occupied by each stage per month, for which samples were available, was calculated to determine if there was a seasonal pattern in spermatogenesis and thus a probable period of mating activity for males.

\section{Females}

The female reproductive tract was observed to assess maturity (Table I) (Stehmann, 2002). Females were considered mature when the largest oocyte was $>3 \mathrm{~mm}$ in diameter (Walker, 2007). The condition and number of enlarged oocytes (>3 mm diameter) per single (right) ovary of each specimen were recorded and the maximum oocyte diameter $\left(D_{\mathrm{MO}}\right)$ was measured to the nearest $1 \mathrm{~mm}$. The condition and contents, if any, of the uteri were recorded and measured to determine fecundity, embryo development and timing of the reproductive cycle. The width of each oviducal gland was measured to the nearest $0.1 \mathrm{~mm}$. The oviducal glands of 33 specimens ( 9 immature and 24 mature) were excised and fixed in $10 \%$ buffered formalin for histological analyses. Once fixed, the oviducal glands were sagittally sectioned, processed and stained following the same protocol as the testes. Sections were viewed under a light microscope to determine if female $M$. asterias store sperm.

The liver mass $\left(M_{\mathrm{L}}\right)$ of each dissected specimen was measured to the nearest $0 \cdot 1 \mathrm{~g}$. The hepato-somatic index $\left(I_{\mathrm{H}}\right)$ was calculated as a measure of condition and plotted against $L_{\mathrm{ST}}$ for each maturity stage: $I_{\mathrm{H}}=100 M_{\mathrm{L}} M_{\mathrm{T}}^{-1}$.

The reproductive tract of males and females was dissected out; gonads were carefully separated from the epigonal organ and weighed $\left(M_{\mathrm{G}}\right)$ to the nearest $0.01 \mathrm{~g}$. The gonado-somatic index $\left(I_{\mathrm{G}}\right)$ was calculated and plotted against $L_{\mathrm{ST}}$ for each maturity stage: $I_{\mathrm{G}}=100 M_{\mathrm{G}} M_{\mathrm{T}}^{-1}$.

All statistical analyses were performed with Microsoft Excel using the data analysis and solver add-ins. The $L_{\mathrm{ST}}$ at which $50 \%$ of males and females were sexually mature was calculated by logistic regression of binomial maturity data (immature $=0$, mature $=1$ ) using the following equation (Conrath \& Musick, 2002): $Y=\left(1+\mathrm{e}^{-(a+b X)}\right)^{-1}$, where $Y$ is the proportion of mature individuals, $X$ is $L_{\mathrm{ST}}$ and $a$ and $b$ are coefficients estimated by fitting a logistic curve to the data. The corresponding age at maturity for males and females was calculated from the age and growth estimates in Farrell et al. (2010).

\section{MALE MATURITY}

The smallest mature male was $72 \mathrm{~cm} L_{\mathrm{ST}}$, while the largest immature male was $85 \mathrm{~cm} L_{\mathrm{ST}}$. The $L_{\mathrm{ST}}$ and age at $50 \%$ maturity for males were estimated to be $78 \mathrm{~cm}$ and 4-5 years (Fig. 2). The upper and lower $95 \%$ CI were 80 and $76 \mathrm{~cm} L_{\mathrm{ST}}$, respectively. The plot of $L_{\mathrm{C}}$ and $L_{\mathrm{ST}}$ showed three distinct phases of clasper growth, relating to three stages of male maturity (Fig. 3). Juveniles (stage A, $n=40,35-72 \mathrm{~cm}$ $L_{\mathrm{ST}}$ ) had very short flexible claspers. Adolescents (stage B, $n=29,60-85 \mathrm{~cm}$ $L_{\mathrm{ST}}$ ) had rapidly elongating claspers. Adults (stage C, $n=44,72-104 \mathrm{~cm} L_{\mathrm{ST}}$ ) had long calcified claspers, the growth of which had slowed considerably. Both testes develop concomitantly in $M$. asterias, and there was no significant difference between the mass of left and right testes (paired $t$-test, d.f. $=142, P>0.05$ ), 


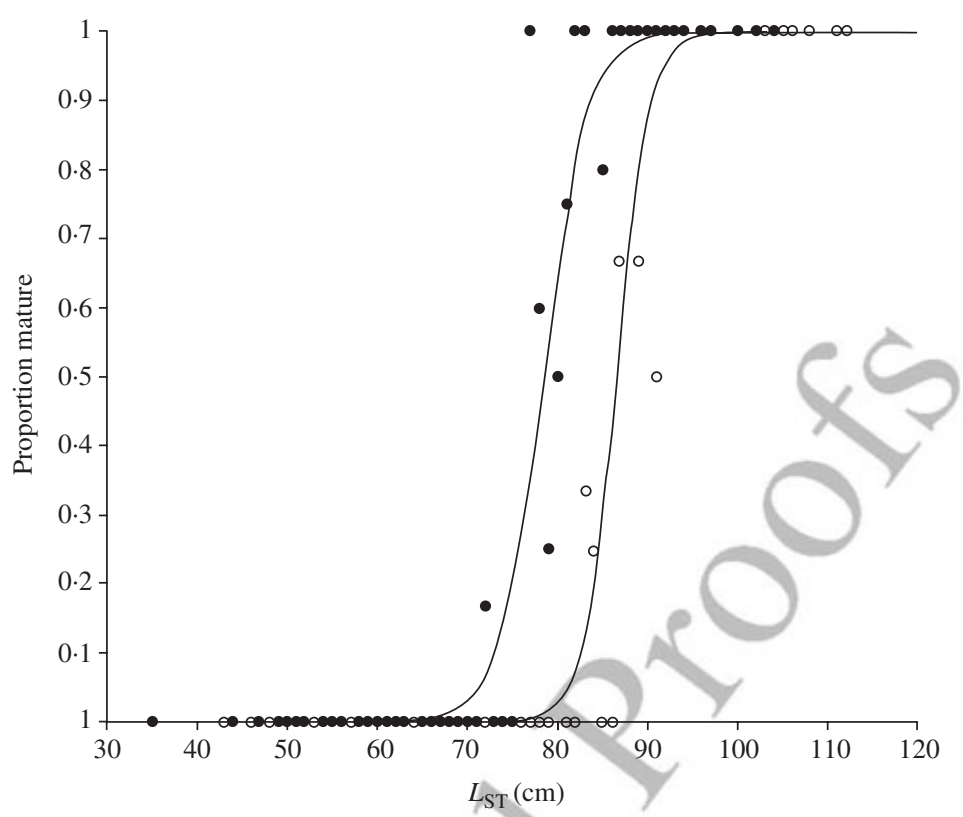

FIG. 2. Maturity ogives for stretch total length $\left(L_{\mathrm{ST}}\right)$ for male $(\bullet)$ and female $(\mathrm{O})$ Mustelus asterias in the northeast Atlantic Ocean. The $L_{\mathrm{ST}}$ at $50 \%$ maturity was 78 and $87 \mathrm{~cm}$ for males and females, respectively.

therefore the mean testes mass was calculated for each specimen. Testes of juvenile $M$. asterias were threadlike, undeveloped and difficult to distinguish from the epigonal organ. The $I_{\mathrm{G}}$ showed a rapid increase in testes growth at $c .70 \mathrm{~cm} L_{\mathrm{ST}}$, which coincides with the adolescent maturity stage and the elongation of the claspers [Figs 3 and 4(a)]. The $I_{\mathrm{H}}$ also increased with $L_{\mathrm{ST}}$, though not as significantly as the $I_{\mathrm{G}}[$ Fig. 5(a)].

\section{FEMALE MATURITY}

The smallest mature female was $83 \mathrm{~cm} L_{\mathrm{ST}}$, while the largest immature female was $91 \mathrm{~cm} L_{\mathrm{ST}}$. The estimated $L_{\mathrm{ST}}$ and age at $50 \%$ maturity for females were estimated to be $87 \mathrm{~cm}$ and 6 years (Fig. 2). The upper and lower 95\% CI were 88 and $84 \mathrm{~cm} L_{\mathrm{ST}}$, respectively. The plot of oviducal gland width and $L_{\mathrm{ST}}$ showed three phases of development (Fig. 6). Juveniles (stage A, $n=62,43-84 \mathrm{~cm} L_{\mathrm{ST}}$ ) had small flattened, undeveloped oviducal glands with an average width of $0.37 \mathrm{~cm}$. Adolescents (stage B, $n=22,69-91 \mathrm{~cm} L_{\mathrm{ST}}$ ) showed a marked increase in oviducal gland width, average $1.08 \mathrm{~cm}$, and development. Adult (stages C, D, E and F, $n=$ $19,3,1$ and 11 , respectively, $83-112 \mathrm{~cm} L_{\mathrm{ST}}$ ) had large swollen oviducal glands with an average width of $2.09 \mathrm{~cm}$. The $I_{\mathrm{G}}$ increased concomitantly with oviducal gland width for stage $\mathrm{B}$ and some stage $\mathrm{C}$ females, indicating the onset of maturity [Fig. 4(b)]. Some stage $\mathrm{C}$ females, however, have a very low $I_{\mathrm{G}}$, which is similar to that of stages $\mathrm{E}$ and $\mathrm{F}$ females. The $I_{\mathrm{H}}$ increased with $L_{\mathrm{ST}}$ for all maturity stages except stage $\mathrm{F}$ females, which displayed a marked decline in the $I_{\mathrm{H}}$, consistent with a substantial postovulation maternal investment in the embryos [Fig. 5(b)]. 


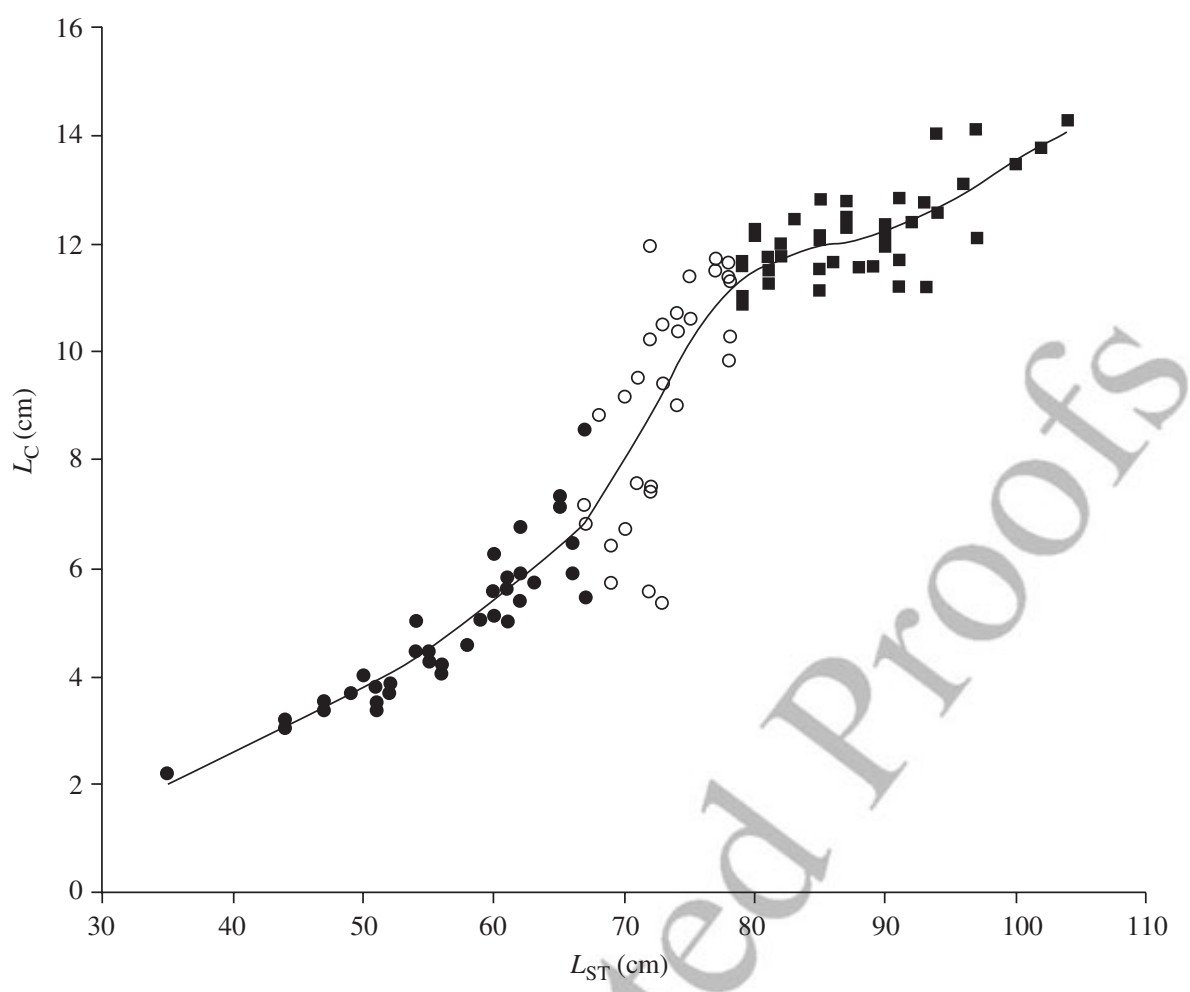

FIG. 3. The relationship between clasper length $\left(L_{\mathrm{C}}\right)$, maturity and stretch total length $\left(L_{\mathrm{ST}}\right)$ for male Mustelus asterias in the north-east Atlantic Ocean stages: A $(\bullet)$, B (O) and C ( $\boldsymbol{\square})$. A loess curve is fitted to the data; $r^{2}=0.93$.

\section{FECUNDITY}

Ovarian fecundity ranged from eight to 27 yellow, spherical oocytes and uterine fecundity from six to 18 embryos. The maximum was observed in a $111 \mathrm{~cm} L_{\mathrm{ST}}$ female, which had nine embryos in each uterus. There was no significant difference between the contents of left and right uteri (1:1.016) in females (paired $t$-test, d.f. $=13, P>0.05)$ or between the numbers of male and female embryos (1:1.04) in each litter (paired $t$-test, d.f. $=10, P>0.05$ ). The relationship between uterine fecundity $\left(F_{\mathrm{U}}\right)$ and $L_{\mathrm{ST}}$ was curvilinear and described by the equation: $F_{\mathrm{U}}=$ $0.00004 L_{S T}^{2.6395}\left(r^{2}=0 \cdot 39\right)$. Pregnant females were, however, occasionally observed to abort and expel embryos when caught, therefore values of uterine fecundity may be underestimates.

\section{EMBRYO DEVELOPMENT AND GESTATION}

Stage D females with uterine eggs were observed in April and June. Uterine eggs were oval, yellow, measured $28-43 \mathrm{~mm}$ in length and weighed $3.8-7.5 \mathrm{~g}$ each. Each was contained within a brown transparent egg envelope, secreted by the oviducal gland. One stage E female, with developing embryos $\left(8 \mathrm{~cm} L_{\mathrm{ST}}\right)$ still attached to a large yolk sac, was observed in January. Small stage F embryos with 


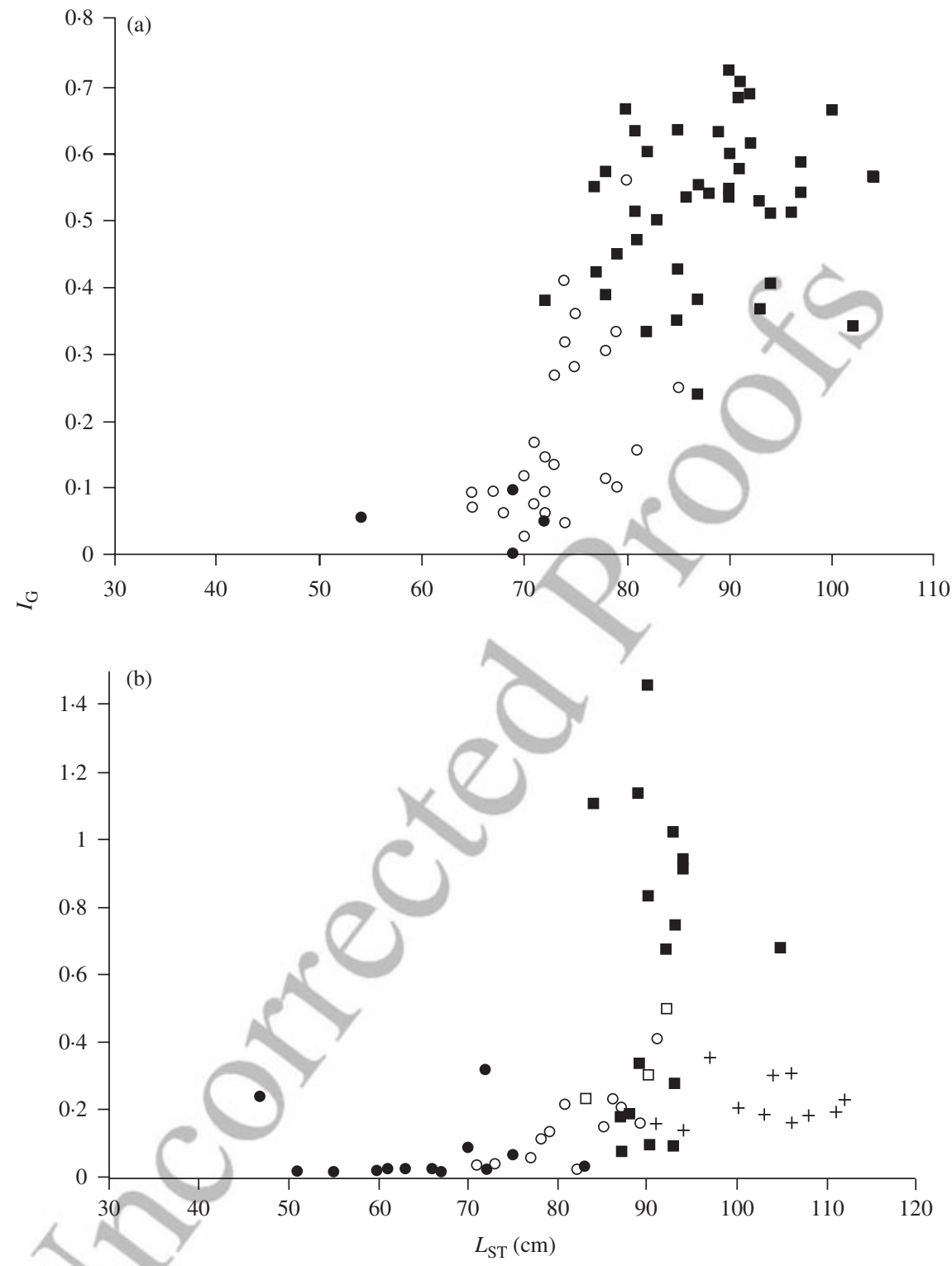

FIG. 4. The gonado-somatic index $\left(I_{\mathrm{G}}\right)$ in relation to stretch total length $\left(L_{\mathrm{ST}}\right)$ for (a) male and (b) female Mustelus asterias in the north-east Atlantic Ocean. The variation with maturity stage is also shown [stages A $(\bullet), \mathrm{B}(\mathrm{O}), \mathrm{C}(\boldsymbol{\square}), \mathrm{D}(\square), \mathrm{E}(\bullet)$ and F (+)].

both unfixed pigmentation, i.e. pigmentation that is not fully developed and can be rubbed off easily $\left(21 \mathrm{~cm} L_{\mathrm{ST}}, 23.7 \mathrm{~g}\right)$, and fixed pigmentation $\left(22.5 \mathrm{~cm} L_{\mathrm{ST}}\right.$, $28 \mathrm{~g}$ ) and no yolk remaining in the yolk sac were also observed in January. In April, the fully developed embryos had fixed pigmentation and an average $L_{\mathrm{ST}}$ of $25 \mathrm{~cm}$ and mass of $34 \mathrm{~g}$. In June, stage F embryos had an average $L_{\mathrm{ST}}$ of $27 \mathrm{~cm}$ and mass of $54 \mathrm{~g}$ and in July an average $L_{\mathrm{ST}}$ of $31 \mathrm{~cm}$ and mass of $86 \mathrm{~g}$. Neonate 


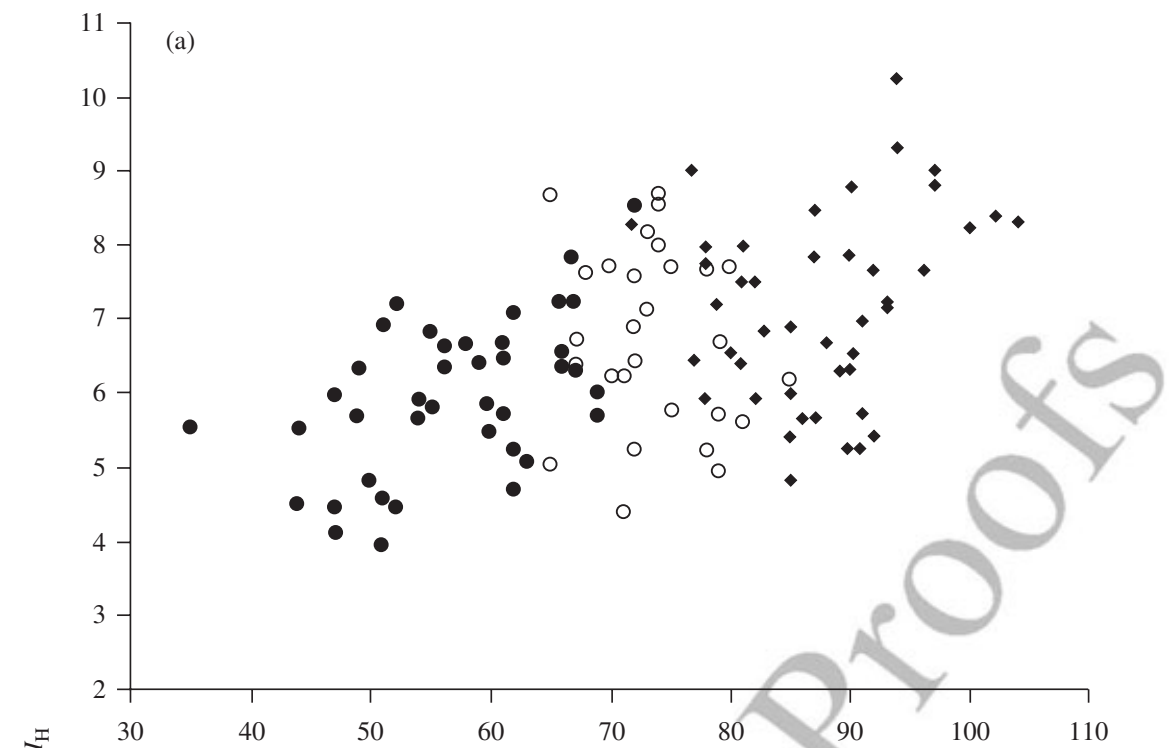

FIG. 5. Hepato-somatic index $\left(I_{\mathrm{H}}\right)$ in relation to for stretch total length $\left(L_{\mathrm{ST}}\right)$ of (a) male and (b) female Mustelus asterias in the north-east Atlantic Ocean. The variation with maturity stage is also shown

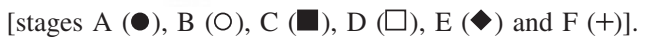

M. asterias with obvious umbilical scars were caught as early as late April and May. The smallest free-swimming $M$. asterias observed during the study was $28 \mathrm{~cm}$ $L_{\mathrm{ST}}$ (May) while the largest in utero embryo was $32 \mathrm{~cm} L_{\mathrm{ST}}$ (July); therefore, the average length at birth was calculated to be $30 \mathrm{~cm} L_{\text {ST }}$. No stage G, post-natal females were observed; specimens in this category may have been confused with 


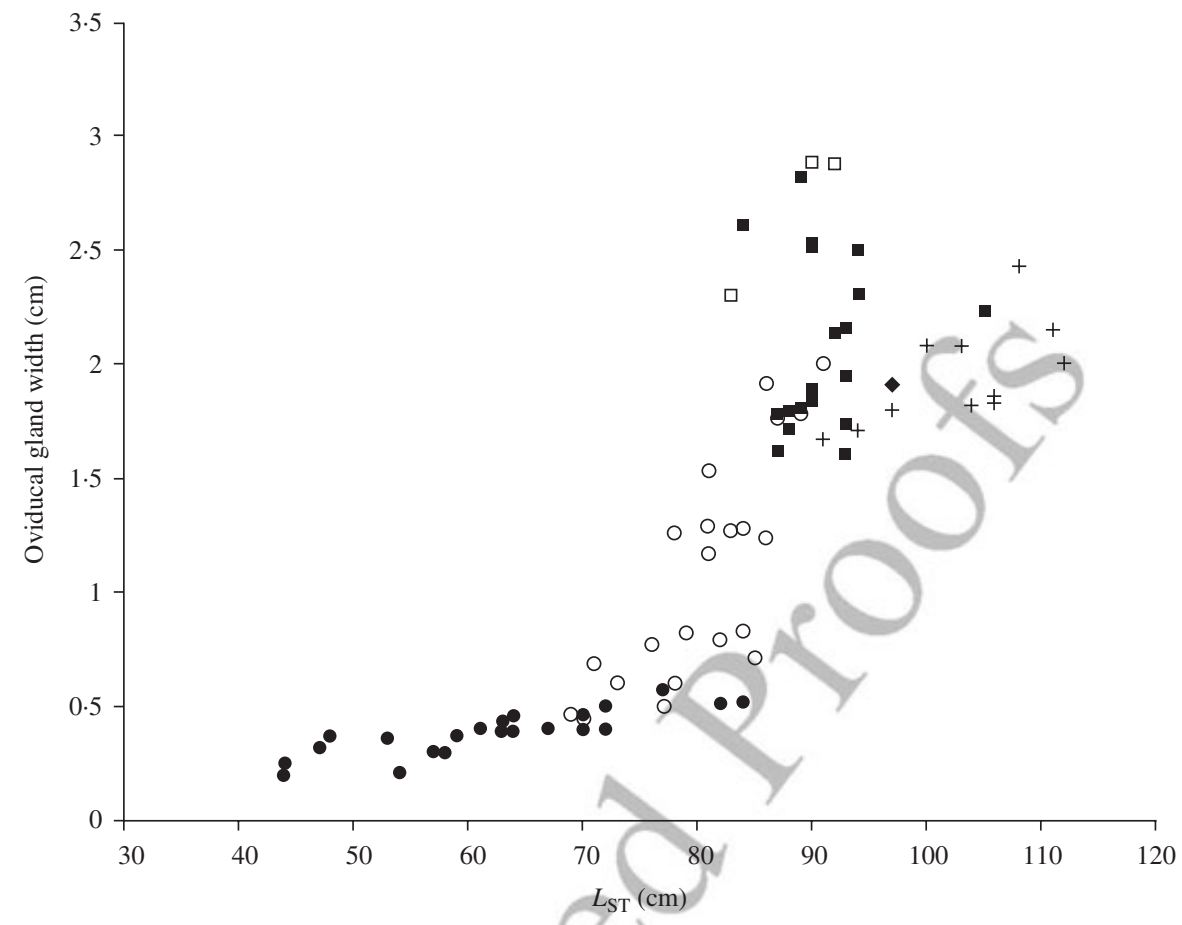

FIG. 6. The relationship between oviducal gland width, maturity and stretch total length $\left(L_{\mathrm{ST}}\right)$ for female

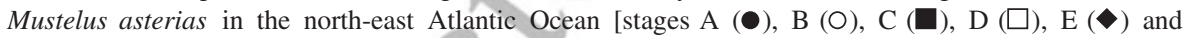
$\mathrm{F}(+)]$.

stage $\mathrm{C}$ individuals, although none were observed with obviously enlarged flaccid post-parturition uteri. The shortest and longest periods between observation of recently ovulated uterine eggs and full-term (fully developed embryos of the birth length) embryos were 11 and 16 months, respectively. Given this and the fact that some degree of asynchronism of embryo development was observed, as illustrated by the occurrence of both stages $\mathrm{E}$ and $\mathrm{F}$ females in January, it is likely that gestation lasts $c .12$ months.

Three full-term (stage F) female specimens also carried undeveloped eggs or underdeveloped and deformed embryos in their uteri. One case of twins was observed in a $112 \mathrm{~cm} L_{\mathrm{ST}}$ female. The two male embryos were together in the same egg envelope and both were underdeveloped compared to the other embryos, $6 \mathrm{~cm}$ shorter and $30 \mathrm{~g}$ lighter than the average embryo size. Unlike some other Mustelus species, no uterine compartments were observed (Yamaguchi et al., 2000; Walker, 2007); however, the egg envelope persisted throughout the pregnancy and was full of clear liquid once the embryo was at stage $\mathrm{F}$ development.

\section{SPERM STORAGE}

The morphology of the oviducal gland of M. asterias [Fig. 7(a)] appeared identical to that of Mustelus antarcticus Günther and Mustelus canis (Mitchill) (Hamlett et al., 1998; Storrie et al., 2008). Thirteen of the 33 sectioned oviducal glands did 

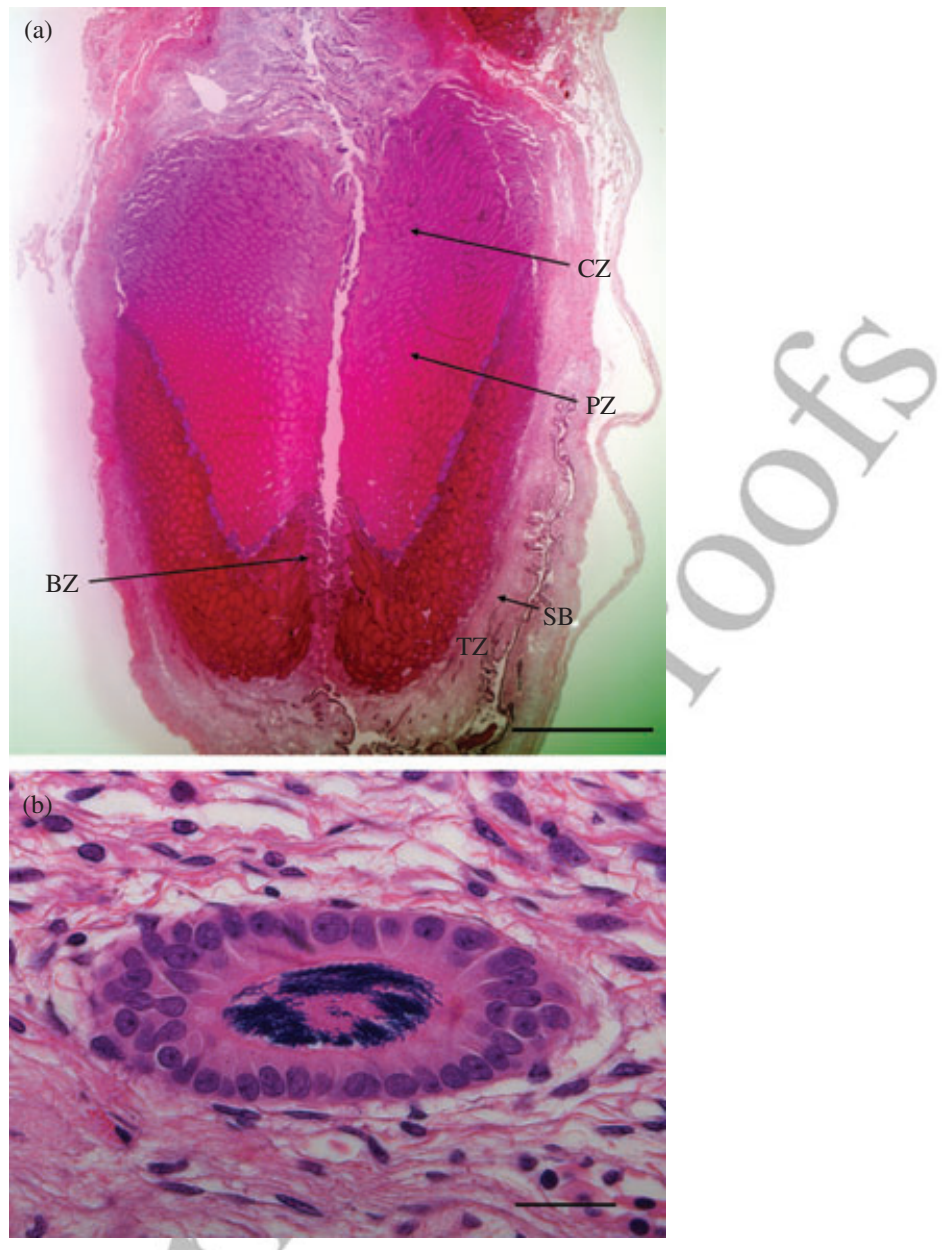

FIG. 7. (a) Sagittally sectioned oviducal gland of a mature Mustelus asterias. CZ, club zone; PZ, papillary zone; BZ, baffle zone; TZ, terminal zone; SB, sperm bundle. Scale bar $=2 \mathrm{~mm}$. (b) A sperm storage tubule containing a sperm bundle. Scale bar $=40 \mu \mathrm{m}$.

not contain any sperm, while 20 contained clearly visible sperm bundles [Fig. 7(b)]. Of these, one was from a stage B immature female and sperm was only present in the terminal zone [Fig. 7(a)]. Two stage $\mathrm{C}$ mature specimens had sperm in the terminal zone, baffle zone and in the lumen of the oviducal gland. The remaining 17 specimens, comprising seven stage $C$, three stage $D$, one stage $E$ and six stage $\mathrm{F}$ individuals, all had sperm bundles in the terminal zone. These specimens were collected over a number of months including January, February, April, June and October; therefore, sperm storage occurs throughout the year.

\section{REPRODUCTIVE CYCLE}

Histological analyses of the testes of mature males (Fig. 8) showed their structure to be similar to those of M. canis (Conrath \& Musick, 2002). Due to the small 


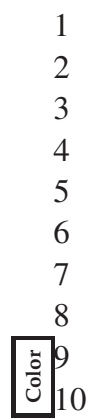

Stage 1

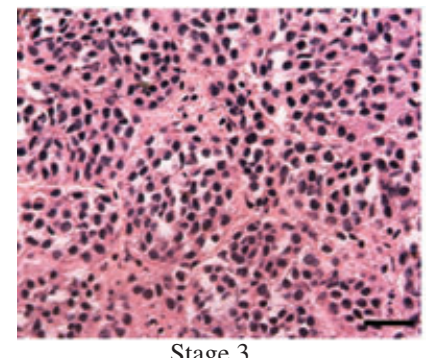

Stage 3

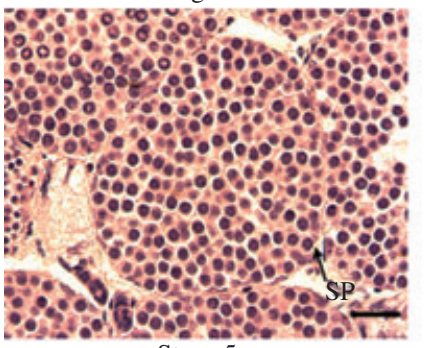

Stage 5

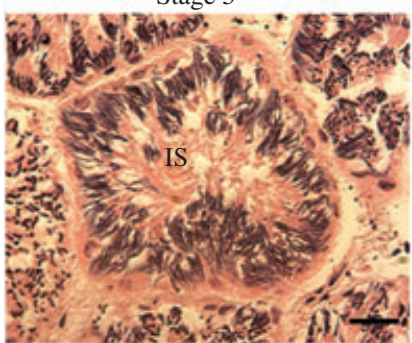

Stage 7

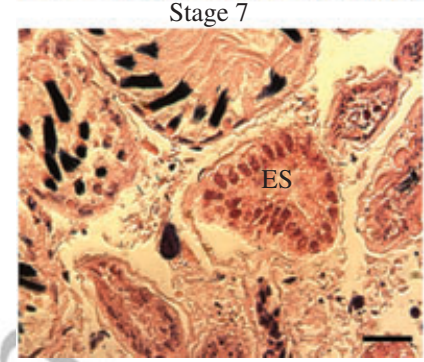

Stage 2

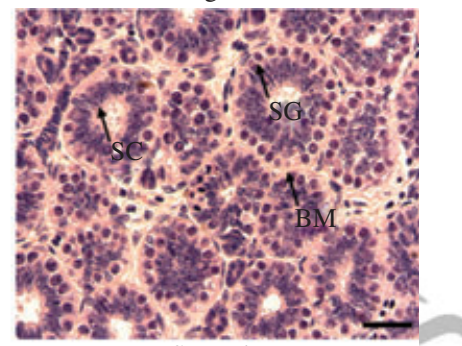

Stage 4

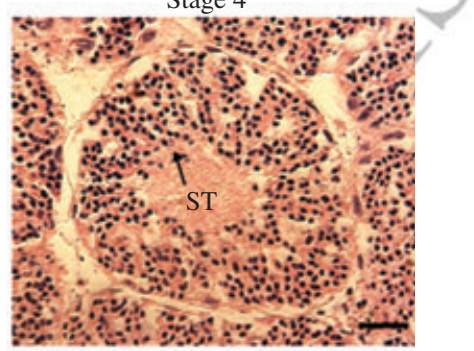

Stage 6

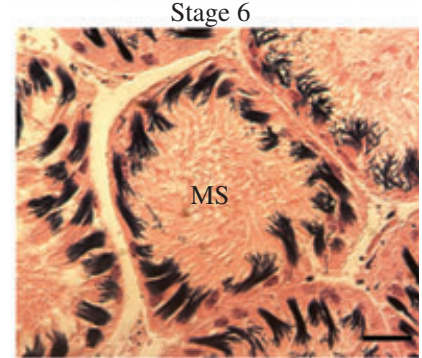

FIG. 8. Sperm stages of Mustelus asterias testes: stages 1 to 7. SG, spermatogonia; SC, sertoli cells; BM, basement membrane; SP, spermatocytes; IS, immature sperm; MS, mature sperm; ES, evacuated spermatocyst; ST, spermatids. Scale bar $=50 \mu \mathrm{m}$.

sample size $(n=44)$, no significant differences in the proportion of sperm stages throughout the year were found. Trends suggest however, that the highest proportion of evacuated spermatocysts (stage 7) and lowest proportion of spermatocysts with mature sperm (stage 6) were observed in June (Fig. 9). Mature males caught in October also often had large amounts of semen in their seminal vesicles and two stage $\mathrm{C}$ females caught in October had sperm in the terminal zone, baffle zone and in the lumen of the oviducal gland. 


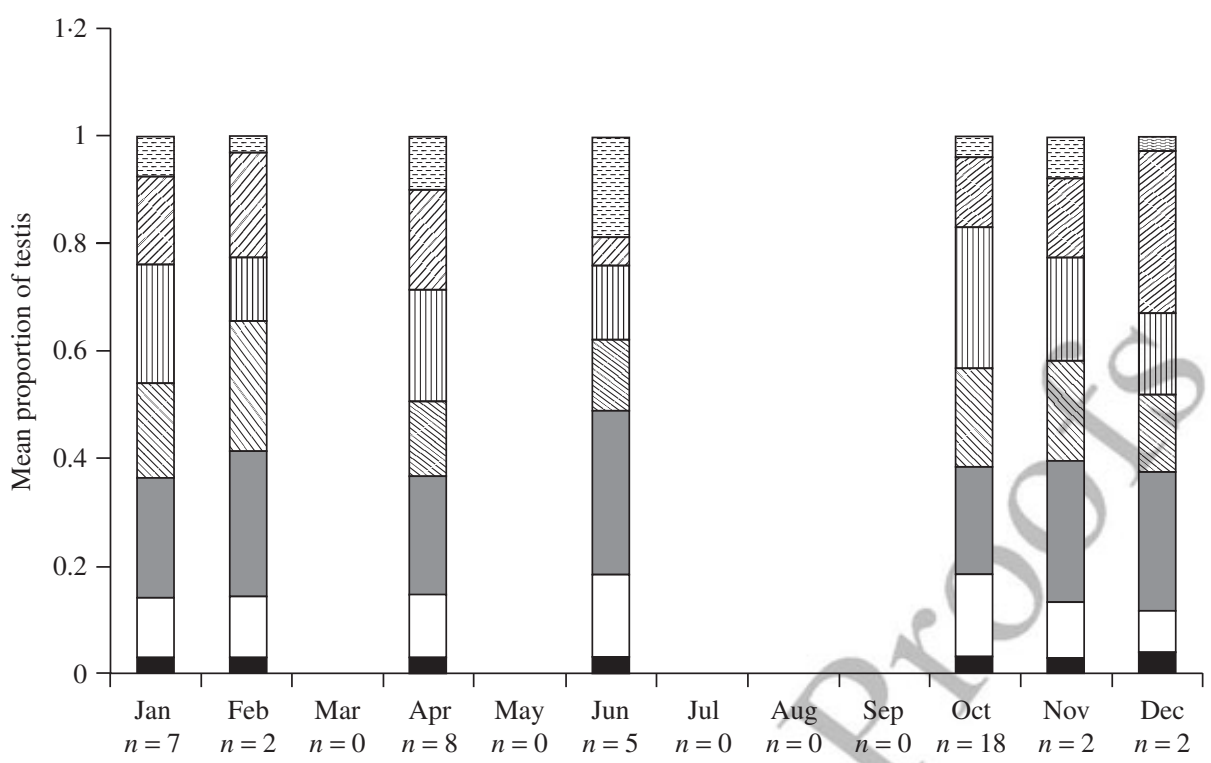

FIG. 9. The mean proportion of the testes of mature male Mustelus asterias $(n=44)$ occupied by each stage

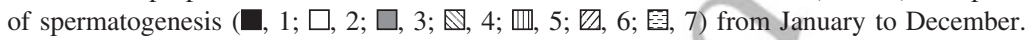

Non-pregnant, mature females had an average $D_{\text {MO }}$ of $6 \mathrm{~mm}$ in April $(n=5)$, $10 \mathrm{~mm}$ in October $(n=7), 14 \mathrm{~mm}$ in November $(n=2)$ and $15 \mathrm{~mm}$ in February $(n=4)$. The widest $D_{\mathrm{MO}}, 23 \mathrm{~mm}$, was observed in a stage D female captured in April, which had ovulated two eggs into each uterus, suggesting that ovulation occurs around this time of year after a $c$. 12 month period of oocyte development. Pregnant females with full-term embryos (stage F) had immature oocytes in the ovaries $(<5 \mathrm{~mm})$. This suggests that females do not become pregnant soon after parturition, but probably have a period of rest, during which oocytes develop to ovulation size. Considering the $c .12$ month gestation period and this post-parturition rest period, the reproductive cycle is most probably biennial.

\section{TAGGING}

One tagged $M$. asterias has been recaptured to date. A female specimen was tagged in May 2008 off Holyhead, Wales, and was recaptured by a commercial fishing vessel near Arcachon in the Bay of Biscay in March 2009 (Fig. 1). After 257 days at liberty, the minimum distance travelled was $1109 \mathrm{~km}$ with a minimum distance travelled per day of $4.3 \mathrm{~km}$ (Fig. 1). Although preliminary, the result of the tagging may have implications for fisheries management.

\section{DISCUSSION}

Mustelus asterias is currently undergoing an apparent upward shift in abundance in the north-east Atlantic Ocean (ICES, 2007). Commercial landings of this species are, however, concurrently increasing (FAO, 2000), and there are no management 
measures in place despite the known vulnerability of European Mustelus species to exploitation (Aldebert, 1997; Quero, 1998; Jukic-Peladic et al., 2001; Correia \& Smith, 2003; Ferretti et al., 2005). The current study provides vital reproductive biological traits of $M$. asterias in the north-east Atlantic Ocean and reveals geographic variation and potential local adaptation in the region.

\section{MATURITY AND FECUNDITY}

Male $M$. asterias mature earlier and at a smaller $L_{\mathrm{ST}}$ than females, which is common among members of the Mustelus genus (Walker, 2007). The estimated $L_{\mathrm{ST}}$ at $50 \%$ maturity for male M. asterias $(78 \mathrm{~cm})$ is similar to the $75 \mathrm{~cm}$ estimated by Capapé (1983) for Mediterranean males. Interestingly though, the $L_{\mathrm{ST}}$ at $50 \%$ maturity for females $(87 \mathrm{~cm})$ is considerably shorter than the $96 \mathrm{~cm}$ estimated by Capapé (1983). The corresponding ages at maturity for male and female M. asterias, 4 to 5 and 6 years, respectively (Farrell et al., 2010), are more than twice those previously estimated (Francis, 1981).

The differences in $L_{\mathrm{ST}}$ at maturity for male $M$. asterias in the north-east Atlantic Ocean and Mediterranean Sea appear negligible; however, for females the differences may suggest a degree of geographic variation. It must be noted, however, that Capapé (1983) did not provide a detailed description of the methods employed for measuring the length of specimens and as such the differences may reflect some degree of methodological bias. If it is assumed that the differences are valid, then a plausible explanation is required. Yamaguchi et al.(2000) found that Mustelus manazo Bleeker populations in higher water temperature matured earlier and at a smaller $L_{\mathrm{ST}}$ than populations living in lower water temperature. The findings of the present study may delineate the opposite pattern in M. asterias, as the north-east Atlantic Ocean has significantly lower water temperatures than the Mediterranean Sea, yet females here reached maturity at a smaller size than in the warmer Mediterranean waters (Capapé, 1983). One possible explanation is that the growth rate in the Mediterranean Sea is higher, although no published age and growth studies are available to confirm this. Limited food availability in warmer waters may have also slowed down the rate of maturity as demonstrated in the bonnethead shark Sphyrna tiburo (L.) (Parsons, 1993). More notably, the observed differences may result from fisheries-induced evolution, plastic response or distortion of the size-frequency compositions of one or more cohorts in the population by size-selective fishing. Walker (2007) found that the length at maturity of $M$. antarcticus increased with rising length-selective fishing mortality from gillnets and subsequently decreased with falling fishing mortality. The level of fishing mortality of $M$. asterias has historically been high in the Mediterranean Sea and low in the north-east Atlantic Ocean and thus length-selective fishing methods may have had an important role in shaping the reproductive characteristics in these regions.

The maximum uterine fecundity of 18 embryos should be viewed with caution as this was observed in a $111 \mathrm{~cm} L_{\mathrm{ST}}$ specimen. The maximum observed $L_{\mathrm{ST}}$ of a reliably identified $M$. asterias in the north-east Atlantic Ocean is $133 \mathrm{~cm} L_{\mathrm{ST}}$ (Farrell et al., 2010). Uterine fecundity increases with $L_{\mathrm{ST}}$, therefore, females of this size would be capable of carrying larger litters than those observed. The relationship between litter size and maternal $L_{\mathrm{ST}}$ has also been described for other aplacental Mustelus species; curvilinear for M. antarcticus (Lenanton et al., 1990; Walker, 
2007) and Mustelus lenticulatus Phillipps (Francis \& Mace, 1980) and linear for M. manazo (Yamaguchi et al., 1997). Capapé (1983) observed a maximum fecundity of 35 embryos in a $125 \mathrm{~cm}$ total length, $L_{\mathrm{T}}$, specimen, which is much greater than the fecundity observed in the present study. This may also be explained by lower water temperature in the north-east Atlantic Ocean than the Mediterranean Sea as litter size in M. manazo decreases with increasing latitude and possibly decreasing water temperature (Yamaguchi et al., 2000), a phenomenon also seen in M. antarcticus (Walker, 2007).

The marked decline in the $I_{\mathrm{H}}$ for stage $\mathrm{F}$ females, carrying full-term embryos, indicates a substantial postovulation maternal investment in the embryos (Figs 4(b) and 5(b)]. This suggests that M. asterias is a matrotrophic species rather than lecithotrophic (Hamlett et al., 2005a; Musick \& Ellis, 2005). The mechanisms of such matrotrophy in the white-spotted Mustelus species appear to be mucoid histotrophy, which has been confirmed in M. antarcticus (Storrie et al., 2009).

\section{GESTATION PERIOD AND BIENNIAL REPRODUCTIVE CYCLE}

The processes of ovulation and parturition within a population do not necessarily occur instantaneously and individuals within that population will probably display a small degree of asynchrony, which complicates the definition of "period of gestation' (Walker, 2007). In this study, the shortest period between observation of uterine eggs and of full-term embryos and free-swimming neonates was 11 months, while the longest period was 16 months. Considering the small degree of asynchrony in embryo development from specimens in January (both stages $\mathrm{E}$ and $\mathrm{F}$ were observed), the gestation period for the population was considered to be $c .12$ months. This is consistent with observations from other aplacental and placental Mustelus species (Francis \& Mace, 1980; Capapé, 1983; Lenanton et al., 1990; Smale \& Compagno, 1997; Yamaguchi et al., 1997; Chiaramonte \& Pettovello, 2000; Conrath \& Musick, 2002; Oddone et al., 2005; Walker, 2007; Saidi et al., 2008, 2009).

Perhaps the most significant finding of the current study is the occurrence of small to medium-sized oocytes in the ovary of full-term (stage $\mathrm{F}$ ) females and the low $I_{\mathrm{G}}$ and $I_{\mathrm{H}}$ [Figs 4(b) and 5(b)]. This indicates that females do not become pregnant soon after parturition, but have a resting period during which oocytes develop to ovulation size. Trends in oocyte development suggest that this process takes $c .12$ months. This scenario contrasts with Mediterranean M. asterias, where full-term pregnant females also had fully enlarged oocytes, meaning that females are capable of becoming pregnant very soon after parturition, with a full female reproductive cycle lasting c. 1 year/(Capapé, 1983). This apparent geographic variation in the duration of the reproductive cycle has also been observed in at least two other species of 'whitespotted' aplacental Mustelus species, M. manazo and M. antarcticus (Yamaguchi et al., 2000; Walker, 2007), with biennial ovarian cycles in populations from colder waters and annual cycles in populations from warmer waters. Until the current study, these were the only two elasmobranch species reported to have ovarian cycles with different periods in separate regions (Walker, 2007). From a management perspective, this is highly important as the productivity of the cold water populations is effectively half that of the warm water populations, which may be further reduced with the lower fecundity observed in colder waters. 


\section{MATING, SPERM STORAGE AND PARTURITION}

Insufficient sample size precluded the determination of a seasonal pattern in spermatogenesis. Trends, however, suggest that testes of males in June had the highest proportion of evacuated spermatocysts (stage 7) and lowest proportion of stage 6 spermatocysts with mature sperm [Figs 8 and 9). Caution should be applied to the interpretation of this result although it suggests that mature sperm were present in the reproductive system at this stage and may be released from the testes at this time and stored until required. Many species of male elasmobranchs have been shown to be able to store sperm in their epididymis or seminal vesicles (Pratt \& Tanaka, 1994). Mature males caught in October also often had large amounts of semen in their seminal vesicles and two mature females captured in October had free sperm in the baffle zone and lumen of the oviducal gland in addition to the sperm bundles in the terminal zone. This suggests that mating may occur at this time of year. These females, however, had a mean maximum oocyte diameter of $9.9 \mathrm{~mm}$, which means it is unlikely that this sperm was used immediately to fertilize eggs and more likely it was destined for storage in the oviducal gland.

Females appear to be able to store sperm for extended periods of time, as even those with full-term embryos had sperm bundles in the terminal zone of the oviducal gland [Fig. 7(a), (b)]. During pregnancy, the uteri are effectively sealed by the uterine sphincter and filled with embryos encased in egg envelopes which should prevent the movement of sperm through the uteri into the oviducal gland (Storrie et al., 2008). Therefore, female M. asterias must store sperm for at least the length of gestation which is $c .12$ months. The observation of sperm in the oviducal gland of one adolescent female is interesting as it means that $M$. asterias mate and store sperm before reaching sexual maturity. This has also been observed in M. antarcticus (Storrie et al., 2008), where sperm was found in the isthmus, uterus and uterine sphincter throughout the reproductive cycle which means that copulation occurs year round in M. antarcticus. In the current study, only the oviducal gland was tested for sperm and it is possible that sperm may have been present in other areas of the female reproductive tract.

Parturition in M. asterias occurs from April to July and neonates have been observed in shallow waters off sandy beaches on the south-east coast of Ireland (E. D. Farrell, pers. obs.). No published information exists on the location of parturition and nursery areas of M. asterias; however, neonates and juveniles are also periodically abundant in shallow areas of the English Channel, southern North Sea and Thames Estuary and Bristol Channel (Fig. 1) (Ellis et al., 2004). In the Irish Sea, large females ( $>90 \mathrm{~cm} L_{T}$ ), many showing obviously distended abdomens, are seasonally abundant in May off Holyhead, Wales (E. D. Farrell, pers. obs.). These aggregations only remain in this area for $c$. 1 month after which they disappear. The one tag returned to date revealed that at least one of these females travelled south from Holyhead to the southern Bay of Biscay (Fig. 1). The gestational stage of this specimen was unknown; however, given the $L_{\mathrm{ST}}$ of $97 \mathrm{~cm}$ upon recapture, it was probably mature. Seasonal migrations of Mustelus species are not unusual (Bigelow \& Schroeder, 1948; King, 1984; Oddone et al., 2005) and female M. lenticulatus and M. antarcticus are known to make considerably further migrations than males, with mature females travelling further than immature females (Francis, 1988). The purpose of such a migration to the Bay of Biscay is unknown and given that only one tag has been returned to date it is difficult to draw meaningful conclusions; however, it 
may be related to seasonal bottom temperature fluctuations in the north-east Atlantic Ocean and food resources. The $I_{\mathrm{H}}$ of stage $\mathrm{F}$ females with full-term embryos was very low as they had utilized their lipid store [Fig. 5(b)]. They could therefore experience nutritional stress as seen in M. lenticulatus (King, 1984) and may have to migrate further to find optimal habitat and resources.

\section{EVOLUTIONARY CONSIDERATIONS AND CONSERVATION}

The geographic variation in reproductive cycle duration, alongside the apparent lack of uterine compartments in M. asterias in the current study and their presence in Mediterranean specimens (Capapé, 1983), underlines the potential for local adaptation of reproductive variables in this species. It also poses interesting evolutionary questions about the developmental biology of M. asterias. Uterine compartments, which form as extensions of the uterine mucosa, are found in all placental and some non-placental sharks (Hamlett et al., 2005b; Storrie et al., 2009). They increase the surface area of the uterus for metabolic exchanges and prevent yolk stalks or umbilical cords becoming tangled or abraded (Storrie et al., 2009). The presence or absence of uterine compartments has actually been used as a criterion in the classification of the genus Mustelus (Whitley, 1945). The present study, however, demonstrates geographic and intraspecific variability in this characteristic. Similar geographic variation has been observed in M. manazo (Yamaguchi et al., 2000), with uterine compartments persisting throughout pregnancy in southerly regions, opposed to a total lack of uterine compartments in the most northern regions. The uterine compartments in intermediate regions formed but disappeared during gestation. The mechanisms underlying these patterns of variability remain unclarified. Although, given their explicit association with remarkably different geographic locations, it is reasonable to expect that they may be related to environmental gradients, such as temperature and dissolved oxygen levels. Such factors are likely to affect metabolic activity and perhaps embryo development, suggesting that spatially explicit intraspecific variation in reproductive traits may have an adaptive value. While the present data do not allow disentangling of the roles of genomic and phenotypic-level mechanisms for this variation, further investigation of these aspects may add to understanding of the reproductive biology of these species and the evolution of the different forms of viviparity.

The ability of the cold water populations to adapt to increasing water temperatures, which are predicted under the climate change scenario, is also of interest. Will the distribution or phenology of these species be forced to change or has it already started to? Recreational anglers have reported catching M. asterias in more northerly areas (Scotland) than they were previously considered to inhabit. Survey data also show that $M$. asterias is currently undergoing an apparent upward shift in abundance in the north-east Atlantic Ocean (ICES, 2007). This should be viewed with caution as the majority of these surveys are conducted in the fourth quarter of the year and as such give a temporally limited view of the abundance of the species. Perhaps warming water temperatures have delayed the movement of $M$. asterias to their winter grounds and as such the abundance is apparently higher than in previous years. While difficult to test and prove, it is worth considering when developing management strategies. 
The aforementioned variations in the reproductive variables of $M$. asterias illustrate the complexity of elasmobranch populations and also the current lack of knowledge of the basic biology of many species. Based on their reproduction and other lifehistory traits (Farrell et al., 2010), the north-east Atlantic Ocean and Mediterranean Sea probably represent two different populations of $M$. asterias. In-depth genetic studies and tagging are needed to delineate these populations, uncover any reproductively isolated sub-populations within these regions, and subsequently develop sound management and conservation measures for this area.

With the introduction of proper management controls, Mustelus species have been shown to support sustainable and stable fisheries (Walker, 1998). In the north-east Atlantic Ocean, most M. asterias are taken as by-catch in mixed demersal fisheries by a number of countries, using a variety of gears and across a large geographic area. They are generally discarded (ICES, 2007) and the survival rate is unknown. When they are landed, it is usually in a number of mixed categories such as 'hounds nei (not elsewhere identified)' and 'smooth-hounds nei' or even as 'dogfish nei' (ICES, 2007). They may even be landed in mixed boxes with tope Galeorhinus galeus (L.) and spurdog Squalus acanthias L. (E. D. Farrell, pers. obs.). This makes it impossible to accurately quantify landings and discards and thus difficult to implement management and conservation strategies for the species, as effective conservation of elasmobranch species requires species-specific monitoring of abundance and rates of mortality caused by exploitation (Dulvy et al., 2000). Further to this, the present study shows that area-specific management for some species is required, in addition to speciesspecific monitoring, in order to account for the variability in reproductive variables.

Currently available life-history evidence (Farrell et al., 2010; this study) calls for the establishment of a management plan for the north-east Atlantic population of M. asterias, although future assessment of the reproductive variables of the species in the North Sea is required, and more thorough stock identification methods should be applied throughout the distribution range of the species. The detailed account of the reproductive biology and cycle, in conjunction with genetic identification methods and age and growth estimates (Farrell et al., 2009, 2010), should be used now to devise conservation and management strategies, while the stock is still in an apparently healthy state (ICES, 2007).

This work was supported by the IRCSET - Embark Initiative and it is part of EDF's $\mathrm{PhD}$ studies. We are grateful to D. Browne, J. Ellis, P.-J. Schön, H. Heessen, D. Stokes, G. Owen, M. O'Cuaig, M. McAuliffe, D. Fee, C. Davis, N. Whittle, M. McLoughlin, the scientists and crew of R.V. Celtic Explorer, R.V. Corystes, R.V. CEFAS Endeavour, F.R.V. Scotia and R.V. Tridens, as well as to all the fishermen and anglers who helped in the collection of samples. We are also grateful to M. Farrell and the Neuropathology Laboratory for help with preparation of histological specimens and to W. Roche and the Central Fisheries Board for the tagging component of the project.

\section{References}

Aldebert, Y. (1997). Demersal resources of the Gulf of Lions (NW Mediterranean) impact of exploitation on fish diversity. Vie et Milieu - Life and Environment 47, 275-284.

Bigelow, H. B. \& Schroeder, W. C. (1948). Sharks. In Fishes of the Western North Atlantic, Part 1 (Parr, A. E. \& Olsen, Y. H., eds), pp. 244-254. New Haven, CT: Sears Foundation for Marine Research, Yale University. 
Capapé, C. (1983). Nouvelles données sur la biologie de la reproduction de Mustelus asterias Cloquet, 1821 (Pisces, Pleurotremata, Triakidae) des côtes Tunisiennes. Vie et Milieu 33, $143-152$.

Chiaramonte, G. E. \& Pettovello, A. D. (2000). The biology of Mustelus schmitti in southern Patagonia, Argentina. Journal of Fish Biology 57, 930-942.

Compagno, L. J. V. (1984). FAO species catalogue. Vol. 4. Sharks of the world. An annotated and illustrated catalogue of shark species known to date. Part 2. Carcharhiniformes. FAO Fisheries Synopsis 125, 251-655.

Conrath, C. L. \& Musick, J. A. (2002). Reproductive biology of the smooth dogfish, Mustelus canis, in the northwest Atlantic Ocean. Environmental Biology of Fishes 64, 367-377.

Cope, J. M. (2006). Exploring intraspecific life history patterns in sharks. Fishery Bulletin 104, 311-320.

Correia, J. P. S. \& Smith, M. F. L. (2003). Elasmobranch landings for the Portuguese commercial fishery from 1986-2001. Marine Fisheries Review 65, 32-40.

Dulvy, N. K., Metcalfe, J. D., Glanville, J., Pawson, M. G. \& Reynolds, J. D. (2000). Fishery stability, local extinctions, and shifts in community structure in skates. Conservation Biology 14, 283-293.

Ellis, J. R., Cruz-Martinez, A., Rackham, B. D. \& Rogers, S. I. (2004). The distribution of chondrichthyan fishes around the British Isles and implications for conservation. Journal of Northwest Atlantic Fishery Science 35, 195-213.

Farrell, E. D., Clarke, M. W. \& Mariani, S. (2009). A simple genetic identification method for Northeast Atlantic smoothhound sharks (Mustelus spp.). ICES Journal of Marine Science 66, 561-565.

Farrell, E. D., Mariani, S. \& Clarke, M. W. (2010). Age and growth estimates for the starry smoothhound (Mustelus asterias) in the Northeast Atlantic Ocean. ICES Journal of Marine Science 67, 931-939.

Francis, M. P. (1981). Von Bertalanffy growth rates in species of Mustelus (Elasmobranchii, Triakidae). Copeia 1981, 189-192.

Francis, M. P. (1988). Movement patterns of rig (Mustelus lenticulatus) tagged in southern New Zealand. New Zealand Journal of Marine and Freshwater Research 22, 259-272.

Francis, M. P. \& Mace, J. T. (1980). Reproductive biology of Mustelus lenticulatus from Kaikoura and Nelson. New Zealand Journal of Marine and Freshwater Research 14, 303-311.

Frisk, M. G., Miller, T. J. \& Fogarty, M. J. (2001). Estimation and analysis of biological parameters in elasmobranch fishes: a comparative life history study. Canadian Journal of Fisheries and Aquatic Sciences 58, 969-981.

Hamlett, W. C., Knight, D. P., Koob, T. J., Jezior, M., Luong, T., Rozycki, T., Brunette, N. \& Hysell, M. K. (1998). Survey of oviducal gland structure and function in elasmobranchs. Journal of Experimental Zoology 282, 399-420.

Hamlett, W. C., Kormarik, C. G., Storrie, M., Serevy, B. \& Walker, T. I. (2005a). Chondrichthyan parity, lecithotrophy and matrotrophy. In Reproductive Biology and Physiology of Chondrichthyes (Hamlett, W. C., ed.), pp. 395-434. Enfield, NH: Science Publishers Inc.

Hamlett, W. C., Jones, C. J. P. \& Paulesu, L. R. (2005b). Placentatrophy in sharks. In Reproductive Biology and Physiology of Chondrichthyes (Hamlett, W. C., ed.), pp. 464-502. Enfield, NH: Science Publishers Inc.

Jukic-Peladic, S., Vrgoc, N., Krstulovic-Sifner, S., Piccinetti, C., Piccinetti-Manfrin, G., Marano, G. \& Ungaro, N. (2001). Long-term changes in demersal resources of the Adriatic Sea: comparison between trawl surveys carried out in 1948 and 1998. Fisheries Research 53, 95-104.

King, K. J. (1984). Changes in condition of mature female rig (Mustelus lenticulatus) from Golden Bay in relation to seasonal inshore migrations. New Zealand Journal of Marine and Freshwater Research 18, 21-27.

Kuparinen, A. \& Merila, J. (2007). Detecting and managing fisheries-induced evolution. Trends in Ecology \& Evolution 22, 652-659.

Lenanton, R. C. J., Heald, D. I., Platell, M., Cliff, M. \& Shaw, J. (1990). Aspects of the reproductive biology of the gummy shark, Mustelus antarcticus Günther, from waters 
off the south coast of Western Australia. Australian Journal of Marine and Freshwater Research 41, 807-822.

Lopez, J. A., Ryburn, J. A., Fedrigo, O. \& Naylor, G. J. P. (2006). Phylogeny of sharks of the family Triakidae (Carcharhiniformes) and its implications for the evolution of carcharhiniform placental viviparity. Molecular Phylogenetics and Evolution 40, 50-60.

Maruska, K. P., Cowie, E. G. \& Tricas, T. C. (1996). Periodic gonadal activity and protracted mating in elasmobranch fishes. Journal of Experimental Zoology 276, 219-232.

Musick, J. A. \& Ellis, J. K. (2005). Reproductive evolution of chondrichthyans. In Reproductive Biology and Physiology of Chondrichthyes (Hamlett, W. C., ed.), pp. 45-71. Enfield, NH: Science Publishers Inc.

Myers, R. A., Baum, J. K., Shepherd, T. D., Powers, S. P. \& Peterson, C. H. (2007). Cascading effects of the loss of apex predatory sharks from a coastal ocean. Science 315, 1846-1850.

Oddone, M. C., Paesch, L. \& Norbis, V. (2005). Reproductive biology and seasonal distribution of Mustelus schmitti (Elasmobranchii: Triakidae) in the Rio de la Plata oceanic front, south-western Atlantic. Journal of the Marine Biological Association of the United Kingdom 85, 1193-1198.

Parsons, G. R. (1993). Geographic variation in reproduction between two populations of the bonnethead shark, Sphyrna tiburo. Environmental Biology of Fishes 38, 25-35.

Pratt, H. L. \& Tanaka, S. (1994). Sperm storage in male elasmobranchs - a description and survey. Journal of Morphology 219, $297-308$.

Quero, J. C. (1998). Changes in the Euro-Atlantic fish species composition resulting from fishing and ocean warming. Italian Journal of Zoology 65, 493-499.

Saidi, B., Bradai, M. N. \& Bouain, A. (2008). Reproductive biology of the smooth-hound shark Mustelus mustelus (L.) in the Gulf of Gabes (south-central Mediterranean Sea). Journal of Fish Biology 72, 1343-1354.

Saidi, B., Bradai, M. N. \& Bouain, A. (2009). Reproductive biology and diet of Mustelus punctulatus (Risso, 1826) (Chondrichthyes: Triakidae) from the Gulf of Gabes, central Mediterranean Sea. Scientia Marina 73, 249-258.

Smale, M. J. \& Compagno, L. J. V. (1997). Life history and diet of two southern African smoothhound sharks, Mustelus mustelus (Linnaeus, 1758) and Mustelus palumbes Smith, 1957 (Pisces: Triakidae). South African Journal of Marine Science 18, 229-248.

Stehmann, M. F. W. (2002). Proposal of a maturity stages scale for oviparous and viviparous cartilaginous fishes (Pisces, Chondrichthyes). Archive of Fishery and Marine Research 50, 23-48.

Stevens, J. D., Bonfil, R., Dulvy, N. K. \& Walker, P. A. (2000). The effects of fishing on sharks, rays, and chimaeras (chondrichthyans), and the implications for marine ecosystems. ICES Journal of Marine Science 57, 476-494.

Storrie, M. T., Walker, T. I., Laurenson, L. J. \& Hamlett, W. C. (2008). Microscopic organization of the sperm storage tubules in the oviducal gland of the female gummy shark (Mustelus antarcticus), with observations on sperm distribution and storage. Journal of Morphology 269, 1308-1324.

Storrie, M. T., Wálker, T. I., Laurenson, L. J. \& Hamlett, W. C. (2009). Gestational morphogenesis of the uterine epithelium of the gummy shark (Mustelus antarcticus). Journal of Morphology 270, 319-336.

Walker, T. I. (1998). Can shark resources be harvested sustainably? A question revisited with a review, of shark fisheries. Marine and Freshwater Research 49, 553-572.

Walker, T. I. (2007). Spatial and temporal variation in the reproductive biology of gummy shark Mustelus antarcticus (Chondrichthyes: Triakidae) harvested off southern Australia. Marine and Freshwater Research 58, 67-97.

Whitley, G. P. (1945). New sharks and fishes from Western Australia, part 2. Australian Zoologist 11, 1-42.

Yamaguchi, A., Taniuchi, T. \& Shimizu, M. (1997). Reproductive biology of the starspotted dogfish Mustelus manazo from Tokyo Bay, Japan. Fisheries Science 63, 918-922.

Yamaguchi, A., Taniuchi, T. \& Shimizu, M. (2000). Geographic variations in reproductive parameters of the starspotted dogfish, Mustelus manazo, from five localities in Japan and in Taiwan. Environmental Biology of Fishes 57, 221-233. 


\section{Electronic References}

FAO (2000). FAO Fisheries Department. Fishery Information, Data and Statistics Unit. FISHSTAT Plus: Universal Software for Fishery Statistical Time Series. Available at http://www.fao.org/fishery/statistics/software/fishstat/en/

Ferretti, F., Myers, R. A., Sartor, P. \& Serena, F. (2005). Long term dynamics of the chondrichthyan fish community in the upper Tyrrhenian Sea. ICES CM 25, 1-34. Available at http://www.ices.dk/products/CMdocs/2005/N/N2505.pdf/

ICES (2007). Report of the Working Group Elasmobranch Fishes (WGEF), 22-28 June 2007, Galway, Ireland. ICES CM 2007/ACFM 27. Available at http://www.ices.dk/products/ CMdocs/CM-2007/ACFM/ACFM2707.pdf/ 


\section{QUERIES TO BE ANSWERED BY AUTHOR}

\section{Queries from the Copyeditor:}

AQ1. Please indicate ' $\checkmark$ ' in the artwork of Fig. 4. 